\title{
HUBUNGAN ANTARA MOTIVASI BERPRESTASI DAN KEBIASAAN BELAJAR MATEMATIKA SISWA DENGAN PRESTASI BELAJAR SISWA
}

\author{
Saifullah $^{* 1}$ dan Muchlis ${ }^{1}$ \\ ${ }^{1}$ Program Studi Pendidikan Matematika, STKIP Bima \\ *Email korespondensi: faithfaqih@gmail.com
}

\begin{abstract}
ABSTRAK
Penelitian ini bertujuan untuk mengetahui apakah terdapat hubungan antara motivasi berprestasi dan kebiasaan belajar matematika siswa dengan prestasi belajar siswa. Penelitian ini merupakan penelitian korelasi yang terdiri dari dua variabel bebas yaitu motivasi berprestasi dan kebiasaan belajar matematika siswa, dan satu variabel terikat, prestasi belajar siswa. Penelitian dilaksanakan di SMP Negeri 5 Kota Bima Kelas VIII-B pada Tahun 2017 dengan sampel 23 orang yang diambil secara proporsional random sampling. Hasil penelitian ini menghasilkan tiga kesimpulan, yaitu: Terdapat Hubungan positif dan signifikan antara motivasi berprestasi dengan prestasi belajar siswa dengan koefisien korelasi $\left(\mathrm{ry}^{1}\right)$ sebesar 0,90 dan koefisien determinasi $\left(\mathrm{r}^{2} \mathrm{y}^{1}\right)$ sebesar $90 \%$ dengan persamaan regresi $\hat{\mathrm{Y}}^{1}=53.832+2.579 \mathrm{X}^{1}$. Hubungan positif dan signifikan antara kebiasaan belajar matematika siswa dengan prestasi belajar siswa, dengan koefisien korelasi $\left(\mathrm{ry}^{2}\right)$ sebesar 0.74 dan koefisien determinasi $\left(\mathrm{r}^{2} \mathrm{y}^{2}\right)$ sebesar ) $74 \%$ dengan persamaan regresi $\hat{\mathrm{Y}}^{1}=7.102+0.742 \mathrm{X}^{2}$. Hubungan positif dan signifikan antara motivasi berprestasi dan kebiasaan belajar matematika siswa dengan prestasi belajar siswa dengan koefisien korelasi $\left(r y^{12}\right)$ sebesar 0.830 dan koefisien determinasi $\left(\mathrm{r}^{2} \mathrm{y}^{12}\right)$ sebesar $83 \%$ dengan persamaan regresi $\hat{Y}^{12}=3.177+0,062 X^{1}+0,753 X^{2}$. Kesimpulan dari penelitian ini adalah bahwa prestasi belajar siswa dapat ditingkatkan melalui peningkatan motivasi berprestasi dan kebiasaan belajar matematika siswa dengan ditunjukan dengan koefisien determinasi 0.830 ini berarti besarnya kontribusi motivasi berprestasi dan kebiasaan belajar matematika siswaa dengan prestasi belajar siswa adalah sebesar $83 \%$.
\end{abstract}

Kata kunci : Motivasi Berprestasi, Kebiasaan Belajar Matematika Siswa, Prestasi Belajar Siswa.

\begin{abstract}
This study aims to determine whether there is a relationship between achievement motivation and students' mathematics learning habits with student achievement. This research is a correlation study consisting of two independent variables, namely achievement motivation and students' mathematics learning habits, and one dependent variable, student learning achievement. The research was conducted in Bima City 5 Middle School Class VIII-B in 2017 with a sample of 23 people taken by proportional random sampling. The results of this study produce three conclusions, namely: There is a positive and significant relationship between achievement motivation and student achievement with a correlation coefficient $\left(\mathrm{ry}^{1}\right)$ of 0.90 and a coefficient of determination $\left(\mathrm{r}^{1} \mathrm{y}^{1}\right)$ of $90 \%$ with a regression equation $\hat{\mathrm{Y}}^{1}=53.832+2.579 \mathrm{X}^{1}$. A positive and significant relationship between students' mathematical learning habits and student achievement, with a correlation coefficient $\left(\mathrm{ry}^{2}\right)$ of 0.74 and a coefficient of determination $\left(\mathrm{r}^{2} \mathrm{y}^{2}\right)$ of $) 74 \%$ with a regression equation $\hat{\mathrm{Y}}^{1}=7.102+0.742 \mathrm{X}^{2}$. Positive
\end{abstract}


and significant relationship between achievement motivation and mathematics learning habits of students with student learning achievement with a correlation coefficient (ry12) of 0.830 and a coefficient of determination $\left(\mathrm{r}^{2} \mathrm{y}^{12}\right)$ of $83 \%$ with a regression equation $\hat{\mathrm{Y}}^{12}=3.177+0.062 \mathrm{X}^{1}+$ $0.753 \mathrm{X}^{2}$. The conclusion of this study is that student learning achievement can be improved through increasing achievement motivation and students 'mathematics learning habits as indicated by the determination coefficient of 0.830 which means the contribution of achievement motivation and students' mathematics learning habits with student learning achievement is $83 \%$.

Keywords: Achievement Motivation, Student Mathematics Learning Habit, Student Learning Achievement

\section{PENDAHULUAN}

Matematika disebut sebagai ratunya ilmu. Secara etimologis perkataan matematika berarti ilmu pengetahuan yang diperoleh dengan bernalar. Tujuan dari pendidikan matematika pada jenjang pendidikan dasar dan menengah adalah menekankan pada penataan nalar dan pembentukan kepribadian (sikap) siswa agar dapat menerapkan atau menggunakan matematika dalam kehidupannya (Soedjadi, 2000:42). Dengan demikian matematika menjadi mata pelajaran yang sangat penting dalam pendidikan dan wajib dipelajari pada setiap jenjang pendidikan.

Matematika merupakan pelajaran yang sampai saat ini oleh para siswa masih dianggap sulit. Padahal, disisi lain, matematika adalah subjek yang penting dalam kehidupan manusia, matematika berperan dalam hampir segala aspek bahkan di masa teknologi dan digital sekarang ini. Dalam paragraph awal dari laporan National Research Council (NRC), Everybody Counts (1989) bahwa matematika adalah kunci dari kesempatan, bukan lagi hanya pada bahasa, melainkan saat ini matematika berkontribusi secara langsung dan mendasar terhadap bisnis, keuangan, kesehatan dan pertahanan.

Setiap individu mempunyai pandangan yang berbeda tentang pelajaran matematika. Ada yang memandang matematika sebagai mata pelajaran yang menyenangkan dan ada juga yang memandang matematika sebagai pelajaran yang sulit bahkan ada yang memandang matematika itu pelajaran yang menyeramkan. Bagi yang menganggap matematika menyenangkan maka akan tumbuh motivasi dalam diri individu tersebut untuk mempelajari matematika dan optimis dalam menyelesaikan masalah-masalah yang bersifat menantang dalam pelajaran matematika. Sebaliknya, bagi yang menganggap matematika sebagai pelajaran yang sulit, maka individu tersebut akan bersikap pesimis dalam menyelesaikan masalah matematika dan kurang termotivasi untuk mempelajarinya serta individu tersebut 
akan menghindari pelajaran matematika. Sikap-sikap tersebut tentunya akan mempengaruhi hasil yang akan mereka capai dalam belajar.

Ada beberapa faktor yang mempengaruhi prestasi belajar siswa yaitu faktor eksternal dan faktor internal. Faktor eksternal meliputi kompetensi guru, sarana dan prasarana sekolah kesejahteraan keluaraga dan sebagainya (Ahmadi dan Supriyono, 2004:138). Sedangkan Faktor internal meliputi intelegensi, motivasi, kebiasaan, kecemasan, minat, dan sebagainya.

Salah satu faktor yang mempengaruh prestasi belajar siswa adalah guru. Aktivitas pengajaran guru yang tidak mengelola secara terprogram, tidak teratur dan tidak mengikuti prinsip-prinsip pengelolaan serta kaidah-kaidah pengajaran yang baik merupakan masalah krusial terhadap pelaksanaan pengajaran. Guru yang hanya menuntut menghafal bahan mata pelajaran dari buku, hubungan personal dengan siswa rendah. Seorang guru yang memberikan mata pelajaran dengan menggunakan metode dan media yang tidak menarik akan mengakibatkan keengganan siswa/i untuk mengikuti pelajaran tersebut. Ketidakhadiran siswa terhadap materi pelalajaran yang disajikan menjadikan siswa sulit untuk memahami materi.

Fasilitas yang minim disekolah turut mempengaruhi hasil belajar siswa (Dimyati dan Mudjiono, 2009:84). Keterbatsan fasilitas laboraturium, buku diperpustakaan. Kamar mandi, kantin, kelas yang tidak memenuhi standar kesehatan sedikit banyak berpengaruh terhadap proses belajar siswa. Tersdeianya sarana/fasilits pendidikan seperti: laboraturium dan perpustakaan yang lengkap dapat meningkatkan keinginan siswa untuk belajar. Sekolah tinggi yang sedikit memiliki raboratium dan buku-buku diperpustakaan yang kurang memadai membuat siswanya sedikit mendapat sumber bacaan dan pengalaman bereksperimen dalam laboraturium.

Dalam penelitian ini, peneliti memfokuskan tentang kaitan beberapa faktor internal pada diri siswa dengan hasil yang dicapai oleh siswa. Faktor- faktor internal tersebut diantaranya adalah faktor non intelektual yaitu motivasi berprestasi dan kebiasaan belajar siswa. Faktor non intelektif diantaranya adalah motivasi dan kebiasaan.

Motivasi merupakan sumber pendorong bagi mahasiswa untuk melakukan aktivitas belajar guna meraih prestasi, dengan memiliki motivasi berprestasi akan melakukan segala upaya belajar agar memperoleh hasil belajar yang memuaskan. Sesuai dengan yang dikemukakan oleh (Hamzah,2011:31) bahwa motivasi berprestasi berpengaruh besar terhadap unjuk kerja seseorang, termasuk dalam belajar. belajar akan lebih cepat dan lebih baik jika 
mereka memiliki sasaran yang akan dicapai. Seseorang yang memiliki motivasi berprestasi tinggi akan cenderung menyelesaikan tugasnya tanpa menunda-nunda, belajar dengan tekun serta berusaha mencapai tujuannya. Motivasi berprestasi didefinisikan sebagai kecenderungan untuk mengupayakan keberhasilan dan memilih kegiatan kegiatan yang berorientasi pada keberhasilan/kegagalan. Penelitian penelitian menunjukan bahwa motivasi memiliki pengaruh yang besar terhadap prestasi belajar. Ini dikarenakan motivasi merupakan pendorong dan penggerak individu yang dapat menimbulkan dan memberikan arah bagi individu untuk melakukan aktivitas-aktivitas tertentu untuk mencapai tujuannya. Standar nilai baik nilai ketuntasan belajar maupun kelulusan yang ditetapkan secara nasional yang harus dicapai oleh siswa dapat meningkatkan motivasi siswa dalam belajar dan berprestasi. Serta membuat siswa tertuntut untuk mengubah kebiasaan belajarnya ke arah yang lebih baik.

Kebiasaan belajar merupakan pola belajar yang ada pada diri siswa yang bersifat teratur dan otomatis (Slameto, 2010:22). Kebiasaan bukanlah bawaan sejak lahir, melainkan kebiasaan itu dapat dibentuk oleh siswa sendiri serta lingkungan pendukungnya. Suatu tuntutan atau tekad serta cita-cita yang ingin dicapai dapat mendorong seseorang untuk membiasakan dirinya melakukan sesuatu agar apa yang diinginkannya tercapai dengan baik. Kebiasaan belajar yang baik akan dapat meningkatkan prestasi belajar siswa, sebaliknya kebiasaan belajar yang tidak baik cenderung menyebabkan prestasi belajar siswa menjadi rendah.

Kebiasaan yang efektif diperlukan oleh setiap individu dalam kegiatan belajarnya, karena sangat berpengaruh terhadap pemahaman dan hasil belajar yang akan diraih. Kebiasaan belajar sangat berkaitan dengan keterampilan belajar yang dimiliki seseorang (Slameto, 2010:55). Keterampilan dalam belajar merupakan suatu cara yang dipakai untuk mendapat pengetahuan atau cara untuk menyelesaikan masalah. Dalam hal ini, keterampilan siswa yang dimaksud yaitu bagaimana cara mengikuti pelajaran, cara belajar, cara membaca dan membuat rangkuman. Cara yang dilakukan siswa berbeda-beda, artinya keterampilan dalam belajar yang dilakukan oleh siswa juga berbeda. Siswa akan menyadari bagaimana cara belajar yang baik, sehingga siswa tersebut menjadi lebih bertanggungjawab akan kegiatan belajarnya. Keterampilan belajar yang baik akan membentuk kebiasaan belajar yang baik pula. Oleh karena itu, pembentukan kebiasaan belajar perlu dikembangkan. Kebiasaan belajar siswa terbentuk di sekolah maupun di rumah. Kegiatan belajar siswa yang dilakukan secara 
berulang-ulang selama mengikuti proses pembelajaran di sekolah maupun kegiatan belajar yang dilakukan di rumah. Kebiasaan belajar yang baik akan menjadi suatu cara yang melekat pada diri siswa, sehingga siswa akan melakukannya dengan senang dan tidak ada paksaan.

Berdasarkan hasil wawancara dengan guru, masih dijumpai kegiatan belajar siswa di SMP Negeri 5 Kota Bima masih yang kurang maksimal. Hal itu menunjukkan belum terbentuknya suatu kebiasaan belajar yang efektif. Pembentukan suatu kebiasaan belajar yang baik dapat dilihat dari aktivitas dan kesiapan belajar siswa pada saat di sekolah. Kegiatan belajar siswa di sekolah seperti antusias siswa dalam mengikuti proses pembelajaran, cara siswa merespon apa yang disampaikan guru, minat belajar siswa, budaya belajar yang sesuai dengan standar pendidikan nasional dan sebagainya. Sebelum proses pembelajaran, siswa harus dipersiapkan dahulu oleh guru seperti mengeluarkan buku mata pelajaran yang akan dipelajari. Beberapa siswa yang tidak membawa buku catatan, menunjukkan bahwa siswa tersebut kurang mempersiapkan diri dalam mengikuti proses pembelajaran. Saat proses pembelajaran, beberapa siswa saja yang aktif, sehingga terlihat mana yang memiliki kesiapan dalam belajar dan mana yang tidak. Sementara, kebiasaan menyontek jawaban teman masih sangat membudaya. Sebagian besar siswa mudah lupa dengan materi yang sudah diajarkan. Sebagai contoh, apabila guru bertanya tentang materi yang sudah diajarkan, siswa cenderung diam dan kurang tanggap dalam menjawab pertanyaan guru. Kemampuan dalam menerima materi pelajaran setiap siswa memang berbeda-beda. Sebagian besar siswa hanya mencoba untuk menghafal materi pelajaran saja. Belajar dengan cara menghafal materi pelajaran, menunjukkan apa yang dipelajari hanya disimpan dalam ingatan jangka pendek, sehingga mudah lupa. Kegiatan belajar yang dilakukan siswa berbeda-beda. Ada siswa yang hanya mendengarkan penjelasan guru langsung paham, namun ada juga siswa yang harus membaca ulang materi yang sudah dijelaskan. Guru harus menjelaskan materi pelajaran secara ulang, baru siswa bisa memahami apa yang telah disampaikan oleh guru. Namun, ada beberapa siswa yang rajin merangkum materi yang disampaikan oleh gurunya. Proses pembelajaran di kelas, siswa perlu diberi latihan soal agar pemahaman tentang materi benar-benar dikuasai. Saat guru memberikan soal latihan, terlihat beberapa siswa yang mengerjakan dengan sungguh-sungguh, namun ada pula yang memerlukan bimbingan khusus. Guru harus berkeliling melihat dan mendampingi siswa dalam proses mengerjakan soal latihan tersebut. 
Kebiasaan belajar yang baik memang harus dibentuk dan ditanamkan sejak dini (Sudjana, 2014: 94). Sejalan dengan itu, peran orang tua sangat berpengaruh dalam pembentukan kebiasaan belajar yang baik. Umumnya, proses pendidikan mulanya diperkenalkan oleh keluarga. Keluarga merupakan lembaga pendidikan yang pertama dan utama. Sebagai mana mestinya tugas orang tua yaitu memantau kegiatan belajar anaknya di rumah. Orang tua yang acuh tak acuh terhadap kegiatan belajar anaknya, tidak memperhatikan kebutuhan-kebutuhan anaknya dalam belajar, hal ini sangat berpengaruh terhadap pembentukan kebiasaan belajar siswa. Perhatian orang tua tidak pernah lepas dalam mempengaruhi kegiatan belajar anaknya. Adapun fasilitas belajar di rumah memengaruhi minat dan motivasi anak dalam kegiatan belajar. Fasilitas yang kurang terpenuhi di rumah menyebabkan siswa kurang termotivasi untuk membiasakan diri belajar teratur.

Respon siswa dalam kegiatan belajar mengajar tergantung dengan metode yang digunakan oleh guru. Sementara itu, hasil ujian semester yang diadakan pada akhir tahun ajaran 2017/2018 menunjukkan tentang ketuntasan belajar matematika siswa yaitu 70\% dari siswa kelas VIII tahun ajaran 2017/2018 tuntas dan 30\% belum tuntas, sedangkan kriteria keberhasilan adalah $85 \%$ siswa tuntas dalam belajar. dari beberapa uraian diatas peneliti bermaksud melakukan penelitian dengan judul Hubungan Antara Motivasi Berprestasi Dan Kebiasaan Belajar Matematika Siswa Dengan Prestasi Belajar Siswa.

\section{METODE PENELITIAN}

Jenis penelitian ini adalah penelitian kuantitatif dengan pendekatan corelational. Perolehan data primer dilapangan menggunakan kuesioner yang disusun berdasarkan indikator-indikator yang ada dalam variabel penelitian. Data primer yang dibutuhkan adalah Prestasi Belajar Siswa, Motivasi Berprestasi dan Kebiasaan Belajar Matematika Siswa. Penelitian ini dilakukan di di SMP Negeri 5 Kota Bima pada tahun pelajaran 2017/2018. Secara Skematis dapat digambarkan sebagai berikut:

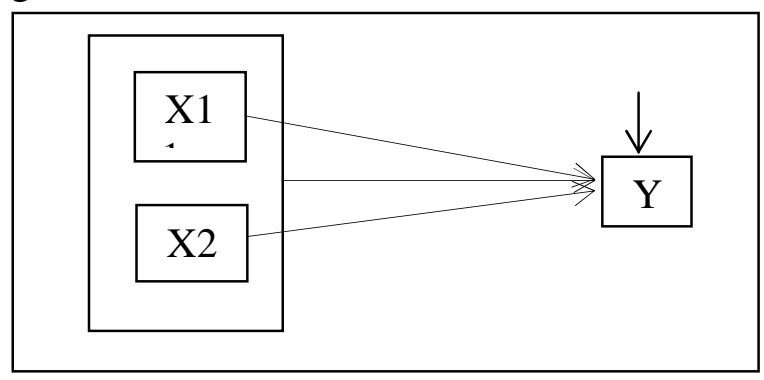

Gambar 1. Konstelasi Masalah Penelitian 
Keterangan :

$\mathrm{X}_{1}=$ Motivasi Berprestasi

$\mathrm{X}_{2}=$ Kebiasaan Belajar Matematika Siswa

$\mathrm{Y}=$ Prestasi Belajar Siswa

$\varepsilon=$ Variabel-Variabel Lain yang Tidak Diteliti

Dalam penelitian ini yang menjadi populasi adalah seluruh siswa kelas VIII SMP Negeri 5 Kota Bima yang berjumlah 92 orang. Analisa dilakukan dua tahap, dengan statistika deskriptif dan dengan statistika inferensial untuk menguji hipotesis dengan teknik korelasi dan regresi.Uji signifikansi menggunakan analisis korelasi Product Moment Pearson. Sebelumnya dilakukan pengujian prasyarat analisis, meliputi uji normalitas metode Lillyefors dan uji homogenitas metode Bartlet's.

Pengujian hipotesis dilakukan dengan teknik uji signifikasi regresi dan korelasi sederhana, serta uji signifikasi regresi dan korelasi ganda. Sementara itu, korelasi parsial digunakan untuk melihat kekuatan hubungan parsial jika salah satu variabel bebas dikontrol.

\section{HASIL DAN PEMBAHASAN}

Dari hasil uji prasyarat analisis pertama yaitu uji normalitas dengan tujuan untuk mengetahui data dari sampel penelitian yang berdistribusi normal. Uji normalitas menggunakan uji liliefors melalui uji Kolmogorov-Smirnov dalam program SPSS For Windows versi 16.0. Jika Lhitung < Ltabel, maka data berdistribusi normal. Jika Lhitung > Ltabel maka data berdistribusi tidak normal. L tabel dengan $\alpha=0,05$ dan $n=23$ diperoleh 1.140. Motivasi berprestasi (X1) diperoleh Lhitung 0,565 < Ltabel $1.140=$ data berdistribusi normal. Kebiasaan belajar siswa (X2) diperoleh Lhitung 0,31 < Ltabel $1.140=$ data berdistribusi normal. Dari hasil uji normalitas dapat disimpulkan bahwa data sampel dari masing-masing variable berdistribusi normal

Tabel 1. Rangkumaan Uji Normalitas Kelompok Data Prestasi Belajar Matematika Siswa (Y) Dengan Motivasi Berorestasi ( $\left.\mathrm{X}^{1}\right)$ Dan Kebiasaan Belajar Siswa $\left(\mathrm{X}^{2}\right)$ dengan menggunakan rumus liliefors

\begin{tabular}{ccccc}
\hline No & Galat taksiran & Lhitung & Ltabel & Kesimpulan \\
\hline 1 & $\mathrm{Y}-\hat{\mathrm{Y}}_{1}$ & 0.565 & 1.140 & Normal \\
& $\mathrm{Y}-\hat{\mathrm{Y}}_{2}$ & 0.31 & 0.385 & Normal \\
& Persyaratan Normal Lh maks $<$ Lo tabel liliefors & \\
\hline
\end{tabular}


Sedangkan pada uji prasyarat analisis yang kedua yaitu uji homogenitas yang berguna untuk mengetahui kelompok data yang berasal dari populasi yang beragam (homogenitas). Uji normalitas menggunakan uji Bartlett melalui uji dalam program SPSS For Windows versi 16.0. Jika $X^{2}$ hitung $<X^{2}$ tabel, maka data berdistribusi homogen. $X^{2}$ tabel dengan $\alpha=0,05$ dan $\mathrm{dk}=17-1$ diperoleh 34,27. Motivasi berprestasi $\left(\mathrm{X}^{1}\right)$ diperoleh $\mathrm{X}^{2}$ hitung $-91,922<\mathrm{X} 2$ tabel 34,27 = data berdistribusi homogen. Kebiasaan belajar siswa $\left(\mathrm{X}^{2}\right)$ diperoleh X2hitung 9, $9413<X^{2}$ tabel $34,27=$ data berdistribusi homogen. Dari hasil uji homogenitas dapat disimpulkan bahwa data sampel dari masing-masing variable berdistribusi homogen.

Tabel 2. Rangkumaan Uji Homogenitas Kelompok Data Prestasi Belajar Matematika Siswa (Y) Dengan Motivasi Berorestasi $\left(\mathrm{X}_{1}\right)$ Dan Kebiasaan Belajar Siswa $\left(\mathrm{X}_{2}\right)$

\begin{tabular}{ccccccc}
\hline No & Kelompok & $\mathrm{n}$ & Dk & $X^{2}$ hitung & $X^{2}$ tabel & Kesimpulan \\
\hline 1 & Y atas $\mathrm{X}^{1}$ & 23 & 17 & -491.922 & 34.27 & Homogen \\
2 & Y atas $\mathrm{X}^{2}$ & 23 & 17 & -9.9413 & 34.27 & Homogen \\
& & Syarat homogen $X^{2}$ hitung $<X^{2}$ table & \\
\hline
\end{tabular}

Hasil uji prasyarat analisis selanjutnya yaitu uji linieritas yang digunakan untuk menguji hubungan variabel-variabel penelitian bersifat linier atau tidak. Kriteria uji linieritas adalah bahwa hubungan yang terjadi berbentuk linier jika Fhitung > Ftabel atau nilai probabilitas signifikansi > 0,05. Dengan menggunakan SPSS For Windows versi 16.0, motivasi berprestasi $\left(\mathrm{X}^{1}\right)$ terhadap prestasi belajar siswa $(\mathrm{Y})$ diperoleh Fhitung sebesar 0,061, nilai ini dikonsultasikan dengan Ftabel pada taraf signifikansi $(\alpha)=5 \%$ sebesar 0.05 , maka dapat diketahui hasilnya adalah $0,061>0,05$, maka dapat disimpulkan antara $\mathrm{X}^{1}$ dan $\mathrm{Y}$ mempunyai hubungan yang linier. Sedangkan pada kebiasaan belajar matematika siswa $\left(\mathrm{X}^{2}\right)$ terhadap prestasi belajar siswa (Y) diperoleh Fhitung sebesar 0,054, nilai ini dikonsultasikan dengan Ftabel pada taraf signifikansi $(\alpha)=5 \%$ sebesar 0.05 , maka dapat diketahui hasilnya adalah $0,054>0,05$, maka dapat disimpulkan antara $\mathrm{X}^{2}$ dan $\mathrm{Y}$ mempunyai hubungan yang linier.

Analisis korelasi dilakukan untuk mengetahui hubungan atau korelasi antara motivasi berprestasi dan kebiasaan belajar matematika siswa terhadap prestasi belajar siswa SPSS For Windows versi 16.0 diperoleh hasil 0,83 dengan nilai signifikansi 0,000 atau $\mathrm{p}<0,05$. Hasil ini menyatakan bahwa terdapat hubungan yang signifikasi antara motivasi prestasi dan kebiasaan belajar matematika siswa terhadap prestasi belajar siswa. 


\section{KESIMPULAN}

Berdasarkan hipotesis penelitian yang diajukan, hasil analisis data, dan pembahasan masalah dapat ditarik kesimpulan bahwa terdapat hubungan positif yang signifikan antara motivasi berprestasi terhadap prestasi belajar siswa. Persamaan regresi antara kedua variabel $\hat{\mathrm{Y}}^{1}=53.832+2.579 \mathrm{X}^{1}$ dan hubungan tersebut bersifat signifikan. Besarnya hubungan ditunjukkan oleh koefisien korelasi sebesar $\left(\mathrm{ry}^{1}\right)$ 0,90, sedangkan koefisien determinasi sebesar $\left(\mathrm{r}^{2} \mathrm{y}^{1}\right)$ 90. Ini berarti besarnya kontribusi antara motivasi berprestasi terhadap prestasi belajar siswa adalah sebesar $90 \%$.

Terdapat hubungan positif yang signifikan antara kebiasaan belajar matematika siswa terhadap prestasi belajar siswa. Persamaan regresi antara kedua variabel $\hat{\mathrm{Y}}^{1}=7.102+$ $0.742 \mathrm{X}^{2}$ dan hubungan tersebut bersifat signifikan. Besarnya hubungan ditunjukkan oleh koefisien korelasi sebesar $\left(r y^{2}\right) 0.74$, sedangkan koefisien determinasi sebesar $\left(\mathrm{r}^{2} \mathrm{y}^{2}\right) 0,74$. Ini berarti besarnya kontribusi kebiasaan belajar matematika terhadap variabel prestasi belajar siswa adalah sebesar $74 \%$.

Terdapat hubungan positif yang signifikan antara motivasi berprestasi dan kebiasaan belajar matematika secara bersama-sama terhadap prestasi belajar siswa. Persamaan regresinya $\hat{\mathrm{Y}}^{12}=3.177+0,062 \mathrm{X} 1+0,753 \mathrm{X}^{2}$ dan hubungan tersebut bersifat signifikan. Besarnya hubungan ditunjukkan oleh koefisien korelasi sebesar (ry ${ }^{12}$ ) 0.830 sedangkan koefisien determinasi sebesar $\left(\mathrm{r}^{2} \mathrm{y}^{12}\right)$ 0,83. Ini berarti besarnya kontribusi motivasi berprestasi dan kebiasaan belajar matematika siswa secara bersama-sama terhadap prestasi belajar adalah sebesar $83 \%$.

\section{REKOMENDASI}

Pemerintah mesti menerapkan kebijakan dan program terkait pengembangan Kualitas Pendidikan di Sekolah SMP/MTs Yang ada di wilayah kota Bima dalam upaya meningkatkan Motivasi Berprestasi dan kebiasaan Belajar siswa untuk meningkatkan prestasi belajar siswa pada mata pelajaran matematika.

Lembaga pendidikan seperti kampus, sekolah, guru, harus mengambil peran dalam upaya memotivasi siswa untuk meningkatkan prestasi belajar siswa lebih khusus pada mata pelajaran matematika. 


\section{UCAPAN TERIMAKASIH}

Ucapan terima kasih kepada bapak kepala sekolah, guru, serta semua unsur yang ada di SMP Negeri 5 Kota Bima Yang telah Membantu memberi informasi secara terbuka sehingga penelitian ini dapat diselesaikan tepat pada waktunya. selanjutnya institusi STKIP Bima yang mensupor berupa memberi suntikan dana serta sahabat dosen yang menyemangati peneliti setiap saat.

\section{REFERENSI}

Ahmadi, A. dan Supriono, W. (2004). Psikologi Belajar. Jakarta: PT Rineka Cipta.

Dimyati dan Mudjiono. (2009). Belajar dan Pembelajaran. Jakarta: Rineka Cipta.

Hamzah B. (2011). Teori Motivasi dan Pengukurannya. Jakarta: Bumi Aksara.

National research council (1989). Everybody counts : A Report to the nation on the future of mathematics education. National academy press. Washington, D.C

Slameto. (2010). Belajar Dan Faktor-Faktor yang Mempengaruhinya. Jakarta: Rineka Cipta.

Sudjana, N. (2014). Dasar-dasar Penelitian Pendidikan. Bandung: Sinar Baru.

Soedjadi R, (2000) Kiat Pendidikan Matematika di Indonesia : Konstatasi Keadaan Masa Kini Menuju Harapan Masa Depan. Jakarta: Direktorat Jenderal Pendidikan Tinggi, Departemen Pendidikan Nasional. 